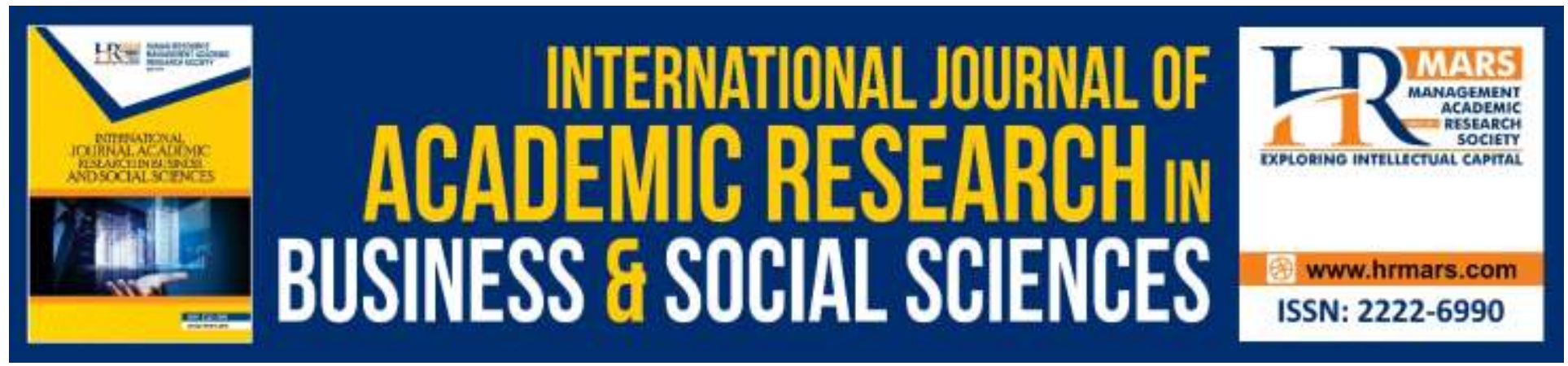

\title{
Mechanism of Corporate Governance and Transparency of Indonesian Companies (Case Study of Manufacturing Companies Listed on the Indonesia Stock Exchange in 2015- 2018)
}

Arumega Zarefar, Raja Adri Satriawan Surya, Atika Zarefar, Vera Oktari

To Link this Article: http://dx.doi.org/10.6007/IJARBSS/v10-i4/7116

DOI:10.6007/IJARBSS/v10-i4/7116

Received: 20 February 2020, Revised: 19 March 2020, Accepted: 29 March 2020

Published Online: 12 April 2020

In-Text Citation: (Zarefar et al., 2020)

To Cite this Article: Zarefar, A., Surya, R. A. S., Zarefar, A., \& Oktari, V. (2020). Mechanism of Corporate Governance and Transparency of Indonesian Companies (Case Study of Manufacturing Companies Listed on the Indonesia Stock Exchange in 2015-2018). International Journal of Academic Research in Business and Social Sciences, 10(4), 149-162.

Copyright: (C) 2020 The Author(s)

Published by Human Resource Management Academic Research Society (www.hrmars.com)

This article is published under the Creative Commons Attribution (CC BY 4.0) license. Anyone may reproduce, distribute, translate and create derivative works of this article (for both commercial and non-commercial purposes), subject to full attribution to the original publication and authors. The full terms of this license may be seen at: http://creativecommons.org/licences/by/4.0/legalcode

Vol. 10, No. 4, 2020, Pg. 149 - 162

http://hrmars.com/index.php/pages/detail/IJARBSS

JOURNAL HOMEPAGE

Full Terms \& Conditions of access and use can be found at http://hrmars.com/index.php/pages/detail/publication-ethics 


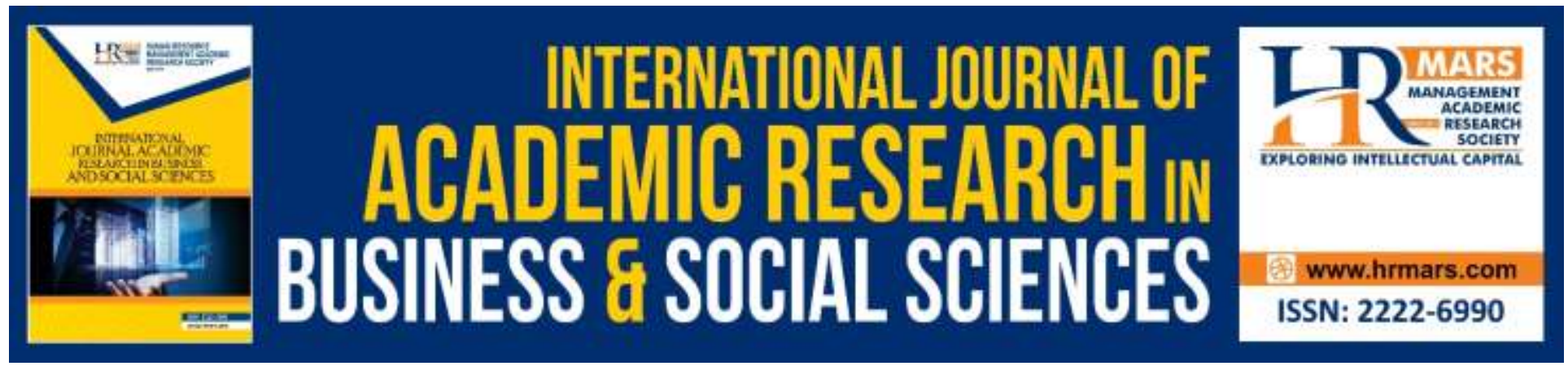

\title{
Mechanism of Corporate Governance and Transparency of Indonesian Companies (Case Study of Manufacturing Companies Listed on the Indonesia Stock Exchange in 2015-2018)
}

\author{
Arumega Zarefar ${ }^{1}$, Raja Adri Satriawan Surya², Atika Zarefar ${ }^{3}$, \\ Vera Oktari ${ }^{1}$
}

${ }^{1}$ Department Accounting, Faculty Economic \& Business, Universitas Riau, Kampus Bina Widya KM. 12,5, Simpang Baru, Kec. Tampan, Kota Pekanbaru, Riau 28293, ²Department Accounting, Faculty Economic \& Business, Universitas Riau, Kampus Bina Widya KM. 12,5, Simpang Baru, Kec. Tampan, Kota Pekanbaru, Riau 28293, ${ }^{3}$ Department Accounting, Politeknik Caltex Riau, Jl. Umban Sari (Patin) No. 1, Kota Pekanbaru, ${ }^{4}$ Department Accounting, Faculty Economic \& Business, Universitas Riau, Kampus Bina Widya KM. 12,5, Simpang Baru, Kec. Tampan, Kota Pekanbaru, Riau 28293

\begin{abstract}
This study aims to examine the influence of corporate governance mechanisms to transparency. Corporate governance mechanisms examined in this study include internal systems including from commissioners, and managerial ownership. Foreign ownership, debt financing, quality audits and company size, firm age as control variables. The population of this research is manufacturing companies listed in the Indonesia Stock Exchange period 2015 - 2018. The research sample is determined by the purposive sampling method with a total sample of 103 annual reports. This study data analysis uses Structural Equation Modeling-Partial Least Square (PLS-SEM).The results showed: the internal governance, debt financing, quality audit, and the size of the company have a significant effect on transparency; while foreign ownership does not affect transparency. The size of the company can be the control variable of transparency, and the age of the company cannot be the control variable to transparency

Keywords: Board of Commissioners, Managerial Own Ownership, Foreign Ownership, Debt Financing, Quality Audits, Company Size, Company Age, Transparency.
\end{abstract}




\section{Introduction}

Timely and accurate disclosure of information about corporate governance is the most important part of corporate governance. This is evidenced by a general understanding of organizational structure, activities and policies. From this organization the company is able to attract investors (Junarso, 2006).

From the global economic crisis that occurred, the main cause of many large companies, including Enron and Worldcom, went bankrupt because it did not show the importance of transparency and lack of good corporate governance. The importance of transparency has been widely recognized by academics and market regulators, so that many rules and regulations are introduced from time to time to ensure timely and reliable disclosure of financial information, creating standards that companies must comply with.

Corporate governance is a system that regulates the company and controls the company or supervises. Many of those who claim that corporate governance is essential to exist in the companies to be able to create an effective and efficient organization. According to Graham et al. (2002), in developing countries such as Indonesia, there are many publicly owned family companies with poor corporate governance costs, which are thus borne by minority shareholders. The way to gain investor confidence is to have good governance that can contribute to better financial disclosure and more transparent business reports.

In this paper, we can provide a framework for understanding the role of transparency in corporate governance. In analyzing the impact of disclosure that has been done and monitoring the relationship between the board and CEO, it can be seen that the quality of company information is revealed as the chosen variable which is an impact on the company and its managers. Through its impact on corporate governance, higher quality disclosures can provide benefits and can impose costs.

Corporate governance is the system of corporate governance related to the theory of agency (Agency Theory). Corporate governance is strongly influenced by the level of transparency of the company. Che Haat et al. in Haryani (2011) states that lack of corporate governance and a low level of transparency in disclosing company information, as well as ineffective enforcement agencies are things that are considered to be the cause of the closure of many companies in Indonesia, such as Sarijaya Permana Sekuritas, Antaboga Sekuritas, and PT. Kimia Farma

The mechanism of corporate governance can be divided into two, namely internal and external mechanisms. The internal mechanism comes from the independent board of commissioners, and managerial ownership. While the external mechanism is audit quality that can be realized if it can meet generally accepted audit standards (Gillan, 2006; Rezaee, 2007),

An independent board of commissioners can actually play a role in reducing agency costs (Gordon, 2007; Gillette, 2008). An independent board of commissioners is made to influence the results of board decisions, such as dismissing an unsuccessful CEO. (Laux, 2008). The independent board of commissioners is very limited to supervise because they do not participate in the company's operational activities.

In addition managerial ownership is the amount of share ownership managed by the management of all the company's share capital. To reduce the problem of fortune, it can be done by aligning the interests between the principal and the agent funds. 
Foreign ownership in a company is considered to be a concern for disclosure. Kozlov et al. (2000) shows that domestic companies are not more productive than foreign companies. Empirical evidence of the statement stated by Fauzi (2008). Fauzi (2008) states that environmental aspects, the achievement of multinational companies outside Indonesia are better than national companies. Hingorani et al. (1997) who concluded that insider ownership and foreign ownership reduce agency problems through incentives that align the interests of managers and investors.

Related to the debt financing structure as part of the corporate governance mechanism, debt is all of the company's financial obligations to other parties that have not been fulfilled from creditors. Bushman et al., ( 2004 ) found that high board structure and ownership are not independent, and these governance variables are related to timeliness and organizational complexity. To overcome agency costs from a high level of ownership concentration, managers and insiders can show willingness to be monitored by creditors such as banks by increasing their public lending (Haat, 2008).

Susiana in Haryani, (2011) which states that audit quality is demanded to be more independent regarding financial statements and annual reports within the company. Quality audit services can have an impact on increasing trust by users of financial statements, so the financial statements can be used as a basis for economic decision making. To increase the value of the company and gain market confidence, the company can use the big four audit services (Haryani, 2011). Based on the p enelitian empirically studied by Haniffa and Cooke (2002) used by the company auditors have a positive relationship to the level of disclosure. This research is in accordance with research conducted by Haryani (2011) which states that the external mechanism in the form of audit quality affects transparency.

Related to company size, to realize and reduce the political costs of large-sized companies can by disclosing various company information (Sembiring, 2005). Large companies are entities that are highlighted by the market and the public in general. One of way to achieve public accountability that transparency is disclosure. Size is also a reflection of the size of the company. a larger company size indicates a higher competitiveness of the company compared to its main competitors and the value of the company will increase because there is a positive response from investors.

Research on corporate governance mechanisms, and transparency is very interesting to be investigated again. If a company has made the implementation of corporate governance well, then it will be more and more information is obtained.

\section{Theory Basis and The Formulation of Hypotheses Agency Theory}

Agency Theory or often called agency theory explains the relationship between two parties, namely the owner (principal) and management (agent). Jensen and Meckling (1976) state agency relationships arise when one or more individuals (principals) pay other individuals (employees or agents) to act on their behalf, delegating the power to make decisions to agents or employees (Purwantini, 2011).

For reduce the agency problem between the owner and the manager, and to align the interests between the owners of the company with the company's management is 
required corporate governance. For direct and control the enterprise in order to achieve a balance between the strength and authority to the company to provide accountability to the shareholders in particular, and stakeholders in general, then designed a system mechanism of corporate governance (Razaee, 2009: 43).

\section{Corporate Governance}

Corporate governance is a governance for companies in applying the principles of fairness, transparency, accountability, and accountability so that it can be used to determine the direction of company performance. According to Cadbury in Wulandari, (2006) corporate governance is a system that regulates and controls or supervises companies. One of the objectives of corporate governance is to provide more awareness and responsibility for companies to the community.

In the absence of corporate management and transparency in running the company would be very damaging, so the company is not DAPT get good grades or strong market to compete with other companies.

\section{Transparency}

Empirical evidence suggests that a material impact on the capital cost can meni incidence of right transparency the better. Transparency is more good and timely reporting on the mentioned can reduce the cost of equity and the transaction costs are lower, reducing errors in the estimates of income, or a higher demand for mailing valuable company (Euromoney Institutional Investor, 2001).

The benefits that can be cited of the transparency of the larger company is reducing the asymmetry of information, and reduce the amount of the periodic surprise about the company's performance and make the share price more st abil (Lang and Lundholm, 1999).

\section{Internal Governance}

In companies independent commissioners are considered capable of giving orders/pressure in order to be able to do transparency. There is a positive relationship between the proportion of independent boards of commissioners who will be neutral in the policies made by directors. The greater the percentage of independent directors, the higher the quality of transparency will be, along with the increase in supervision activities undertaken to reduce the lack of business information obscurity. The board of commissioners is an important component of internal governance that allows for the resolution of problems inherent in the institutions that manage the organization .

Managerial ownership is the percentage of the number of shares owned by the management of the entire share capital of company (Sartono, 2010: 487). Ahmed (2009) states managerial ownership constitute a mechanism of internal control that serves to me monitoring and reduce the conflict to agency. Level managerial ownership own influence the actions of the manager. They will act to maximize their own value. In cases like this the shares owned by the company also owned by the managerial may not be transparent in disclosing information. By greater disclosure than benefit that is received will 
reduce the profits obtained by the company. The management as shareholders have a commitment to the company so they are reluctant to disclose information to outside parties.

Based on the above explanation of the research hypothesis:

H1: Internal governance influences transparency.

\section{Foreign Ownership}

Foreign ownership is a foreign party that also holds a certain amount of shares in a company. These foreign owners also demanded managers to work hard to maximize the value of the company.

Foreign ownership through direct imports and new technology is expected to increase the technology of companies in developing countries (Benfratello and Sembenelli, 2002; Kozlov et al., 2000). Kozlov et al., (2000) showed that the company's domestic turned out to be no more productive than the company's foreign . It is expected that the presence of foreign ownership as an aspect of governance mechanisms will be able to increase transparency in the company. Based on the above explanation of the research hypothesis:

\section{H2: Foreign ownership affects transparency}

\section{Debt Financing}

With regard to debt financing, Bushman et al ., (2004) said that the board structure and high ownership are not independently related to these governance variables, the timeliness of earnings and organizational complexity. Their study shows that transparency and complexity of company operations are the cause of high concentration of ownership. Harvey et al. (2003) found that in emerging markets where extreme information asymmetry exists between the people within the company and outside the company, to signaled their willingness to be monitored by the debt holders of the company then the company uses debt borrowed in international markets. Then the hypothesis can be formulated:

\section{H3: Financing debt affects transparency}

\section{Audit Quality}

Audit quality is always seen as an ability in a company to enhance the quality of financial statements. The existence of a big four auditor who has more quality than a non big four auditor, many companies prefer the big four as their auditor because investors have high trust and will ultimately improve the quality of the company. Based on research conducted by Haniffa and Cooke (2002) companies use auditors who have a relationship to the level of disclosure. As stated by Mitton (2002), that the quality of the audit also become one of the aspects of corporate governance, which is desirable for companies audited by one of the Big Four audit firms (a proxy for quality audit) also will perform better market and transparency the greater one.

Then a hypothesis can be formulated as follows:

H4: Audit quality has a significant effect on transparency. 


\section{Company Size}

In general, large companies will be more transparent in disclosing information compared to smaller companies. Agency theory states that small companies have cost the agency more small than large companies (Jansen \& Mackling, 1976). Larger companies may be revealing more information in an effort to reduce the agency costs. Because demands of shareholders and market analysis of the shareholders of the company requires more disclosure or it can be said that larger companies tend to have a public demand would be the information that is higher than the smaller company. Then a hypothesis can be formulated as follows:

H5: Firm size has a significant effect on transparency.

\section{Company Age}

The more complete a company is, the more information that is obtained by the public about the company, the longer the company can be and the items disclosed by the company more and more as the company's age and experience increases. The age of the company will determine the disclosure made by the company. The older the company, the more resources there will be in making disclosures. So, to prove this, a study was conducted on the effect of company age on Transparency.

Then a hypothesis can be formulated as follows:

H6: Company Agen significant effect on transparency.

\section{METODE Research \\ Population and Sample}

The population in this study are manufacturing companies listed on the Indonesia Stock Exchange (IDX) for the period 2015 - 2018. The sample selection in this study was determined using Purposive Sampling, which is sampling based on criteria, namely:

a. All companies that publish annual reports are listed on the Indonesia Stock Exchange (IDX) in the 2015-2018 annual report.

b. The company includes an annual report along with financial statements that have been audited by an independent auditor.

The sample used in this study was 103 annual company reports . 
INTERNATIONAL JOURNAL OF ACADEMIC RESEARCH IN BUSINESS AND SOCIAL SCIENCES

Vol. 10, No. 4, April, 2020, E-ISSN: 2222-6990 (C) 2020 HRMARS

\section{Operational Definition and Variable Measurement}

\begin{tabular}{|c|c|c|c|c|}
\hline Variable & $\begin{array}{l}\text { Variable } \\
\text { Type }\end{array}$ & Acronym & Operationalization & Resources \\
\hline $\begin{array}{l}\text { Board of } \\
\text { Commissioners } \\
\text { composition }\end{array}$ & Exogenous & DEKOM & $\begin{array}{l}\text { The percentage of independent directors } \\
\text { divided by the total board of commissioners. }\end{array}$ & $\begin{array}{l}\text { Company annual } \\
\text { report for 2015- } \\
2018\end{array}$ \\
\hline $\begin{array}{l}\text { Managerial } \\
\text { ownership }\end{array}$ & Exogenous & INCIDER & $\begin{array}{l}\text { Percentage of shares retained by owners in } \\
\text { (i.e. shares issued to management and } \\
\text { directors) }\end{array}$ & $\begin{array}{l}\text { Indonesia Stock } \\
\text { Exchange online } \\
\text { company } \\
\text { database, taken } \\
\text { from } \\
\text { www.idx.co.id }\end{array}$ \\
\hline $\begin{array}{l}\text { Foreign } \\
\text { Ownership }\end{array}$ & Exogenous & FOREIGN & $\begin{array}{l}\text { The proportion of shares owned by foreign } \\
\text { shareholders to the total shares outstanding. }\end{array}$ & $\begin{array}{l}\text { Investor essence } \\
\text { (December } \\
\text { 2018) which } \\
\text { shows foreign } \\
\text { share ownership } \\
\text { in 2015-2018 }\end{array}$ \\
\hline Debt Financing & Exogenous & DEBT & Long-term debt divided by total assets & $\begin{array}{l}\text { Company annual } \\
\text { report for 2015- } \\
2018\end{array}$ \\
\hline Audit Quality & Exogenous & AUDIT & $\begin{array}{l}\text { Dichotomous; } 1 \text { with Big4 KAP, and } 0 \text { if not } \\
\text { using Big4 KAP }\end{array}$ & $\begin{array}{l}\text { Company annual } \\
\text { report for 2015- } \\
2018\end{array}$ \\
\hline Company Size & Control & UP & $\begin{array}{l}\text { The total asset figure is a proxy for company } \\
\text { size }\end{array}$ & $\begin{array}{l}\text { Company annual } \\
\text { report for 2015- } \\
2018\end{array}$ \\
\hline Company Age & Control & AGE & $\begin{array}{l}\text { The natural logarithm of the number of years } \\
\text { since the company was founded. }\end{array}$ & $\begin{array}{l}\text { Company annual } \\
\text { report for 2015- } \\
2018\end{array}$ \\
\hline Transparency & Indogen & TRANSPA & $\begin{array}{l}\text { Corporate governance reporting scores } \\
\text { are based on disclosure items in } \\
\text { the Indonesian corporate governance general } \\
\text { guidelines issued by KNKG (2006). }\end{array}$ & $\begin{array}{l}\text { Company annual } \\
\text { report for 2015- } \\
2018\end{array}$ \\
\hline
\end{tabular}

This research was conducted using the Structural Equation Model (SEM) approach using Partial Least Square (PLS) software, namely warpPLS software version 6.0.

\section{Results and Discussion}

The following is an overview of research data on a sample of manufacturing companies listed on the IDX for the period 2015 - 2018. 
INTERNATIONAL JOURNAL OF ACADEMIC RESEARCH IN BUSINESS AND SOCIAL SCIENCES

Vol. 10, No. 4, April, 2020, E-ISSN: 2222-6990 @ 2020 HRMARS

Table 1: Descriptive Statistics Results

\begin{tabular}{lr|r|r|r|r} 
& \multicolumn{5}{c}{ Descriptive Statistics } \\
& $\mathrm{N}$ & Minimum & Maximum & mean & Std. Deviation \\
\hline DEKOM & 325 & .25 & 1.00 & .5968 & 197789 \\
\hline INCIDER & 32 & .76 & 1.57 & 1.2858 & .28086 \\
\hline FOREIGN & 325 & .00 & .93 & 1956 & 29732 \\
\hline DEBT & 324 & -2.22 & 8.29 & -.0885 & 1.42410 \\
\hline AUDIT & 325 & .00 & 1.00 & .4246 & .49505 \\
\hline UP & 324 & .00 & 12.41 & 3.4737 & 3.70471 \\
\hline AGE & 321 & .48 & 1.61 & 1.2724 & 266110 \\
\hline T RANSPA & 325 & .21 & .86 & .5284 & .13966 \\
\hline Valid N & 32 & & & & \\
(listwise) & & & & & \\
\hline
\end{tabular}

Table 1 shows the result of the descriptive statistics of variables studied which cover the minimum and maximum values (both theoretical and actual), mean, and the standard deviation (SD). From the descriptive analysis of the variables, it can be inferred that the level of DEKOM (0.5968), INCIDER (1.2858), FOREIGN (1956), DEBT (0.0885), AUDIT (0.4246), UP (3.4737), AGE (1.2724), TRANSPA (0.5284).

\section{Measurement Model Analysis}

Measurement model analysis is used to evaluate the relationship between measures and constructs by assessing the reliability and validity of the masures (indicators) in relation to specific constructs (Solihin et al, 2011). The first step is the assessment of validity. Construct validity is assessed for both convergent validity and discriminant validity. Convergent validity is assessed using the factor loading and average variance extracted (AVE). Table 2 shows that AVE

values for all constructs (Authentic leadership, psychological safety, and internal whistleblowing intention) are above 0.50. Furthermore, factor loading of all instruments of the model are significant $(p<0.01)$ and greater than 0.60 . The result demonstrates an acceptable convergent validity (Latan \& Ghozali, 2014). 
INTERNATIONAL JOURNAL OF ACADEMIC RESEARCH IN BUSINESS AND SOCIAL SCIENCES

Vol. 10, No. 4, April, 2020, E-ISSN: 2222-6990 @ 2020 HRMARS

Table 2. Reliability, Convergent Validity, and Correlation

\begin{tabular}{|l|l|l|l|l|l|l|l|l|l|}
\hline \multicolumn{9}{|c|}{} & \multicolumn{9}{|c|}{ Correlation } \\
\hline Variable & $\begin{array}{l}\text { Composite } \\
\text { Reliability }\end{array}$ & AVE & tkl & Foreign & Debt & Audit & $\begin{array}{l}\text { Timeli } \\
\text { ness }\end{array}$ & Disc & $\begin{array}{l}\text { Tobin's } \\
\text { Q }\end{array}$ \\
\hline Dekom & 0.672 & 0.506 & $(0.932)$ & & & & & & \\
\hline Insider & 0.672 & 0.506 & $(0.932)$ & & & & & & \\
\hline Foreign & 1.000 & 1.000 & 0.000 & $(1.000)$ & & & & & \\
\hline Debt & 1.000 & 1.000 & 0.000 & 0.000 & $(1.000)$ & & & & \\
\hline Audit & 1.000 & 1.000 & 0.000 & 0.000 & 0.000 & $(1.000)$ & & & \\
\hline UP & 0.660 & 0.493 & 0.278 & -0.184 & -0.009 & -0.323 & $(0.872)$ & & \\
\hline AGE & 0.660 & 0.493 & -0.361 & 0.240 & 0.011 & 0.420 & 0.000 & $(0.771)$ & \\
\hline TRANSPA & 1.000 & 1.000 & 0.000 & 0.000 & 0.000 & 0.000 & 0.000 & 0.000 & $(1.000)$ \\
\hline
\end{tabular}

Discriminant validity assesses whether a construct shares more variance with its measures than with other constructs. It is evaluated by comparing the square root of AVE compared to the correlations among the latent constructs (Hair et al., 2012; Hair et al., 2014). When the square root of AVE of a construct is greater than the correlation between the construct with another construct, it is deemed valid. Table 2 shows that the square root of the AVE are all greater than the respective correlation between constructs. The results of the discussion above demonstrate adequate driscriminant validity.

The second step is to use the composite reliability to evalute the construct measures' internal consistency reliability. As shown in Table 2, the composite reliability for each variable is above 0.70 , which demonstrates that each variable has an acceptable reliability (Hair et al., 2012; Hair et al., 2014).

\section{Discussion}

Table 4.11: Indirect Effect Hypothesis Test Results

\begin{tabular}{lllllll}
\hline $\mathrm{H}$ & Hypothesis testing & $\begin{array}{l}\text { Path } \\
\text { coefficie } \\
\mathrm{nt}\end{array}$ & $\begin{array}{l}\text { Effect } \\
\text { Size }\end{array}$ & $\begin{array}{l}\text { Stand } \\
\text { ard } \\
\text { Error }\end{array}$ & P-value & Information \\
\hline $\mathrm{H} 1$ & TKL $\rightarrow$ TRANSPA & -0.243 & 0.070 & 0.053 & $<0.001$ & $\begin{array}{l}\text { Significantly } \\
\text { influential }\end{array}$ \\
\hline $\mathrm{H} 2$ & FOREIGN $\rightarrow$ TRANSPA & 0.080 & 0.014 & 0.055 & 0.073 & No effect \\
\hline $\mathrm{H} 3$ & DEBT $\rightarrow$ TRANSPA & 0.094 & 0.011 & 0.055 & 0.044 & $\begin{array}{l}\text { Significantly } \\
\text { influential }\end{array}$ \\
\hline $\mathrm{H} 4$ & AUDIT $\rightarrow$ TRANSPA & 0.240 & 0.063 & 0.053 & $<0.001$ & $\begin{array}{l}\text { Significantly } \\
\text { influential }\end{array}$ \\
\hline $\mathrm{H} 5$ & UP $\rightarrow$ TRANSPA & -0.113 & 0.017 & 0.055 & 0.019 & $\begin{array}{l}\text { Significantly } \\
\text { influential }\end{array}$ \\
\hline H6 & AGE $\rightarrow$ TRANSPA & 0.085 & 0.009 & 0.055 & 0.061 & No effect \\
\hline
\end{tabular}

Source: Secondary Data Processed, WarpPLS Version 6.0 (2019)

*: Statistically significant at $5 \%$ alpha level ( $\alpha$ : 0.05$)$ 
Internal governance (TKL) has the effect of small, negatively and significantly to transparency. Then it can be concluded that $\mathbf{H} \mathbf{1}$ was accepted.

This indicates that companies that have good TKL will reduce information asymmetry in the level of transparency between outsiders and insiders, and between institutional shareholders and minority shareholders. The results of this study received support from Che Haat (2008) who concluded that internal governance (TKL) affects transparency.

Foreign ownership (FOREIGN) has no small, negative and significant influence on transparency. Then it can be concluded that $\mathbf{H} \mathbf{2}$ is rejected. The reason for rejecting $\mathrm{H} 2$ is that by having company shares to show the company's credibility, there are demands made by foreign parties. This is not in line with the research of Che Haat (2008) which stated that foreign investors have a better ability in determining investment choices. Therefore, management will try to reveal more information to be more transparent, so that it is considered credible and responsible in running the company's operations.

The amount of funding (DEBT) has a positive, and significant influence on transparency. So we can conclude that $\mathbf{H} \mathbf{3}$ was accepted. The test results show that debt financing influences transparency. The level of transparency represented by disclosure is influenced by the high or low value of the debt that the company has. This is in line with the results of research conducted by Che Haat (2008).

Quality of audit (AUDIT) have the effect of small, positive and significant impact on transparency. So we can conclude that $\mathbf{H 4}$ was accepted. The results of this test show that audit quality variables proxied by KAP size affect transparency. This research is in line with the work conducted by Che Haat (2008), which states that there is a relationship between audit quality and transparency, however, it is not in line with research conducted by Nugrahadi (2008).

The company's size (UP) has a small, positive and significant influence on transparency. It can be concluded that the $\mathbf{H} \mathbf{5}$ was accepted. Acceptance of this hypothesis is in line with previous studies (Che Haat, 2008; Fitriany, 2001; Gunawan, 2000). Company size is a predictor variable that can explain variations in transparency in the company's annual report. According to Lang and Lundhom (1993) large-scale companies are always under pressure and financial analysis to provide various information therefore large-scale companies will tend to be more transparent compared to small-sized companies.

Company age (AGE) has a small, positive and significant effect on transparency . So we can conclude that $\mathbf{H} \mathbf{5}$ was accepted. This hypothesis is not in line with previous studies (Che Haat, 2008 ). This is because the company that has an older age does not affect the information disclosure or company transparency which experience possessed more in publishing information on the disclosure of financial statements.

\section{Conclusions, Limitations and Suggestions Conclusion}

Based on the results of the analysis and discussion previously explained, it can be concluded that the results of this study indicate that Internal governance variables have a significant effect on transparency. Because the implementation of good corporate governance is the foundation for the formation of systems, structures, corporate culture that are flexible and 
adaptive to changes in competitive environments and able to build reliable internal control and risk management systems. Transparency provides an effective and responsive communication tool in obtaining information about the company, so that all stakeholders are able to understand the company's performance and actions. The foreign ownership variable has a significant effect on transparency. With foreign shares owned by the company, there is a demand for management to show the company's credibility. Audit quality variable has a significant effect on transparency. The scope of the auditor in this case only acts as an advisor and provides an opinion on the presentation of financial statements that are mandatory disclosures. Debt financing variable does not significantly influence transparency. The level of transparency represented by disclosure and accuracy of reporting time is not influenced by the high or low value of the debt that the company has but with the debt, will cause interest to be paid by the company, so that managers will try to improve company performance.

From the results of this study in the future can add some suggestions, among others; further research can add research variables such as managerial ownership. Using a sample of companies that are not only in manufacturing companies, but can be developed using a sample of banking companies. Future studies are expected to use a longer observation period so that it will provide more to obtain the truth.

\section{References}

Aman, H., Nguyen, P. (2008). "Do stock process reflects the corporate governance quality of Japanese firm" Journal of the Japanese and International Economics 22, pp. 67-662.

Arifin. (2005). Financial Theory and Capital Markets. Yogyakarta: Economical.

Bushman, R., Chen, Q., Engel, E., and Smith, A. (2004), "Financial accounting information, organizational complexity and corporate governance systems", Journal of Accounting and Economics, Vol. 37, pp. 167-201.

Haat, C. M. H., Mahenthiran, S., Abdul Rahman, R., and Abdul Hamid, N. (2005), "Factors that cause companies to be suspended from the Kuala Lumpur Stock Exchange (KLSE)", working paper, presented at the 6th Asia-Pacific Journal of Accounting and Economics (APJAE) Symposium, Guangzhou, 7-8 January.

Dahya, J., Lonie, A. A., and Power, D. M. (1996), "The case for separating the roles of Chairman and CEO: an analysis of stock market and accounting data", Corporate Governance - An International Review, Vol. 4, pp. 71-7.

Davis, G. F., and Thompson, T. A. (1994), "A social movement perspective on corporate control", Administrative Science Quarterly, Vol. 39 No. 1, pp. 141-66.

Donaldson, L., and Davis, J. H. (1991), "Stewardship theory and agency theory: CEO governance and shareholder returns", Australian Journal of Management, Vol. 16 No. 1, pp. 49-63.

Dye, R. (1993), "Auditing standards, legal liability and wealth auditors", Journal of Political Economy, Vol. 101, pp. 887-914.

Eisenhardt, K. M. (1989), "Agency theory: an assessment and review", Academy of Management Review, Vol. 14 No. 1, pp. 57-74.

Euromoney Institutional Investor, 2007. Plc

Fauzi, H. (2008).Corporate Social and Financial Performance: Emprical Evidance from American Companies. Globsyn Management Journal. Vol 3 No1. 
Fitriany. (2001). Significance of the Difference in the Level of Completeness of Mandatory and Voluntary Disclosures in the Financial Statements of Public Companies Listed on the Jakarta Stock Exchange. National Symposium on Accounting IV

Forker, J. J. (1992), "Corporate governance and disclosure quality", Accounting \& Business Research, Vol. 22, pp. 111-24.

Forum for Corporate Governance in Indonesia. (2003), FCGI Corporate Governance Self Assessment Checklist .

Francis, J., Khurana, I., and Pereira, R. (2003), "The role of accounting and auditing in corporate governance and the development of financial markets around the world", Asia Pacific Journal of Accounting and Economics, Vol. 10, pp. 1-31.

Gillan, S. L. (2006). Recent developments in corporate governance: An Overview. Journal of Corporate Finance 16, 381-402.

Ghozali, Imam. \& Latan, H. (2014). Partial Last Squares: Concepts, Techniques and Applications Using the second edition of the SmartPLS3.0 Program. Diponegoro University, Semarang.

Gunawan, Y. (2000). Analysis of Disclosure of Annual Report Information in Companies Listed in the Jakarta Stock Exchange. National Symposium on Accounting VIII

Haniffa, R. M., and Cooke, T. E. (2002), "Culture, corporate governance and disclosure in Malaysian corporations", ABACUS, Vol. 38 No. 3, pp. 317-49.

Harvey, C. R., Liechty, J. C., Liechty, M. W., and Mu "ller, P. (2003), "Portfolio selection with higher moments", working paper, Drexel University, Philadelphia, PA.

Hingorani, A., Lehn, K., and Makhija, A. (1997), "Investor behavior in mass privatization: the case of the Czech Voucher Scheme", Journal of Financial Economics , Vol. 44, pp. 349-96.

Jensen, M. C., and Meckling, W. H. (1976), "Theory of the fi rm: managerial behavior, agency costs and ownership structure", Journal of Financial Economics, Vol. 3, pp. 303-60.

Junarso, Tri.2006. Comprehensive Aproach to Corporate Governance. Austria: iUniverse, Inc.

Kozlov, Y. K., Melentieva, N., and Ponomareva, N. (2000), "Does foreign ownership matter? ", Working paper, available at: www.ssrn.com/paper.taf?abstract_id 1/4 257081

Lang, M. H., and Lundholm, R. J. (1993). Cross Sectional Determinant of Analyst Rating of Corporate Disclosure. Journal of accounting research, 31, 246-271.

Lang, M., and Lundholm, R. (1999), "Corporate disclosure policy and behavior analysts", Accounting Review, Vol. 71, pp. 467-93.

Makhija, A. K., and Spiro, M. (2000), "Ownership structure as a determinant of share value: evidence from newly privatized Czech fi rms", Financial Review, Vol. 35, pp. 1-32.

Marwata. (2001). Financial performance, stock prices and stock splits. "Indonesian Accounting Research Journal, Volume 4 No.2.

Mohamad, N. (2002), "Corporate governance in Malaysia", PhD dissertation, University of Birmingham, Birmingham.

Murhadi, Werner, R. (2013). Analysis of Financial Statements, Projection and Stock Valuation. Jakarta: Salemba Empat.

Purwantini, V. T. (2011). Effect of Good Corporate Governance Mechanisms on Company Value and Corporate Financial Performance (Study of Manufacturing Companies Listed on the IDX). STIE AUB Surakarta. 
Rechner, P. L., and Dalton, D. R. (1991), "CEO duality and organizational performance: a longitudinal analysis", Strategic Management Journal, Vol. 12, pp. 155-60.

Zabihollah, R. (2009). Corporate Governance and Ethics, Jhon Wiley \& Sons. Inc. Sembiring, Eddy Rismanda. Company Characteristics and Disclosure of Social Responsibility. National Symposium on Accounting VIII.

Ndaruningpuri, W. (2006), "The Influence of Indicators of Corporate Governance Mechanisms on the Performance of Public Companies in Indonesia". Thesis Diponegoro University. 